\title{
Postprandial metabolic events and fruit-derived phenolics: a review of the science
}

\author{
Britt Burton-Freeman ${ }^{1,2} *$ \\ ${ }^{1}$ The National Center for Food Safety and Technology, Illinois Institute of Technology, Moffet Campus, 6502 South Archer Road, \\ Summit-Argo, IL 60501, USA \\ ${ }^{2}$ Department of Nutrition, University of California, Davis, CA 95616, USA
}

(Received 27 January 2010 - Revised 28 May 2010 - Accepted 2 August 2010)

There is increasing evidence that the postprandial state is an important contributing factor to chronic disease. The role of fruit phenolic compounds to protect health and lower disease risk through their actions in mitigating fed-state metabolic and oxidative stressors is of interest and the topic of the present paper. Two main questions are posed: first, what is the role of plant foods, specifically fruits rich in complex and simple phenolic compounds in postprandial metabolic management; and second, does the evidence support consuming these fruits with meals as a practical strategy to preserve health and lower risk for disease? This review provides an overview of the postprandial literature, specifically on the effect of fruits and their inherent phenolic compounds in human subjects on postprandial lipaemia, glycaemia/insulinaemia and associated events, such as oxidative stress and inflammation. Among the identified well-controlled human trials using a postprandial paradigm, $>50 \%$ of the trials used wine or wine components and the remaining used various berries. Notwithstanding the need for more research, the collected data suggest that consuming phenolic-rich fruits increases the antioxidant capacity of the blood, and when they are consumed with high fat and carbohydrate 'pro-oxidant and pro-inflammatory' meals, they may counterbalance their negative effects. Given the content and availability of fat and carbohydrate in the Western diet, regular consumption of phenolic-rich foods, particularly in conjunction with meals, appears to be a prudent strategy to maintain oxidative balance and health.

Plant bioactives: Phenolics: Oxidative stress: Inflammation: LDL: Berries

During the past decade, it has become increasingly clear that oxidative stress and inflammation are key features in a number of chronic diseases, most notably those with metabolic roots. Plant foods, particularly fruits and vegetables, have been consistently identified in epidemiological research as the key components of dietary patterns that reduce risk for the development of chronic diseases, including atherosclerotic CVD, insulin resistance and type II diabetes and many cancers ${ }^{(1-3)}$. While total diet analyses take into account food-nutrient interactions and synergism between food components, it is of interest to examine specific food components that contribute to the total dietary effects. Bioactive compounds in foods that elicit physiologic responses to modulate processes of metabolism, oxidative stress and inflammation, which in turn promote health and reduce disease risk, are of particular importance and the focus of the present paper.

There is increasing evidence that the postprandial state is an important contributing factor to chronic disease ${ }^{(4-9)}$. The postprandial state is a dynamic period of metabolic trafficking, biosynthesis and oxidative metabolism of absorbed substrate, such as glucose, lipids, proteins and other dietary constituents. During this period, nearly every major biological system, organ, tissue and cell is responding with compensatory and adaptive mechanisms managing the short-term disturbance to restore balance/homoeostasis. Under optimal conditions, the tilt from balance is modest allowing for rapid system recovery and negligible opportunity for unfavourable stress. In developed societies, there is ready access to nutrients and a modern lifestyle that favours excessive intake of energy, limited energy expenditure and de-emphasises the value of plant-based foods. This combined with the fact that most people eat several times a day results in exaggerated and prolonged metabolic, oxidative and immune imbalance, presenting opportunity for biological insult that over time could supersede biological defence and repair systems manifesting in cellular dysfunction, disease and ultimately death.

While the postprandial period presents opportunity for system disorder, particularly in light of modern eating patterns, this is also an opportunity for protection and intervention. Recently, we reported that consumption of flavonoid-rich strawberries delivered in a semi-liquid beverage along with a moderately high fat and carbohydrate meal, representing typical western eating patterns after an overnight fast, significantly reduced postprandial insulin and TAG responses and blocked the postprandial rise in oxidised LDL compared with consumption of a non-flavonoid-containing placebo beverage

Abbreviations: GSE, grape seed extract; NO, nitric oxide; ROS, reactive oxygen species.

* Corresponding author: B. Burton-Freeman, email bburton@iit.edu; bbfreeman@ucdavis.edu 
over a $6 \mathrm{~h}$ period in overweight men and women ${ }^{(10)}$. Of interest is that in the meal plus placebo beverage condition, the concentration of both oxidised LDL and inflammatory factors were still increasing at $6 \mathrm{~h}$. By then $(6 \mathrm{~h})$ most people would have already eaten another meal. Hence, in the strawberry condition, the next meal would have been consumed against a background similar to the fasting (basal) state, whereas in the placebo condition, the next meal would have presented on a background where oxidised LDL and inflammatory factors were increasing, suggesting a probable compounding of an already activated postprandial state. Since western eating patterns include eating multiple meals a day, including snacks, one can only speculate on the level of biological unrest.

Given this background, two main questions arise. First, what is the role of plant foods, specifically fruits rich in complex and simple phenolic compounds in postprandial metabolic management; and second, does the evidence support consuming these fruits with meals as a practical strategy to preserve health and lower risk for disease? In an attempt to answer these questions, the postprandial literature has been reviewed to address the effect of fruits and their inherent phenolic compounds in human subjects on postprandial lipaemia, glycaemia/insulinaemia and associated events, such as oxidative stress and inflammation. It is anticipated that this discussion will extend our understanding of the diet/ fruit-disease/health benefit relationship.

\section{Fruit phenolic compounds: general background}

The protective effect of fruit and vegetable intake has been attributed to the bioactivity of vitamins, minerals and fibre, and more recently, phytochemicals, particularly phenolic compounds $^{(11-14)}$. Phenolic compounds are widely distributed throughout the plant kingdom and range from simple molecules such as phenolic acids to complex polymerised compounds (i.e. polyphenols) ${ }^{(15)}$. Flavonoids, together with phenolic acids, are a major subclass of polyphenols and are the most abundant polyphenols in the human $\operatorname{diet}^{(15-19)}$. The subclasses of flavonoids include flavonols such as quercetin and kaempferol, flavones (e.g. luteolin and catechins), flavan-3-ols (e.g. catechins), isoflavones (e.g. genistein), the anthocyanidins (e.g. pelargonidin) and the proanthocyanidins, to a name a few ${ }^{(15)}$. Flavonoids, along with other phenolic compounds, are believed to modulate several biological processes related to disease risk in human subjects including oxidative stress, platelet function ${ }^{(20,21)}$, inflammation ${ }^{(22,23)}$ and cancer initiation and propagation ${ }^{(24,25)}$. As such, these compounds have been implicated in promoting health by attenuating disease-inducing processes and have recently captured the interest of many health professionals, researchers, government agencies and even the lay public.

\section{Fruit phenolic compounds: qualifying fruits}

Fruits, like other plant foods, are natural vehicles of phenolic compounds; however, they differ remarkably in content, composition and bioavailability ${ }^{(26-28)}$. As such, there has been tremendous effort to provide a common system for qualifying and ranking fruits and linking this system to expected biological activity in human subjects. However, so far, there is no unifying scheme that relates varieties of fruit to specific health benefits, specifically due to the incomplete nature of the available data.

Fruits may be classified based on the quantity of dominant phenolic compounds present in them; for instance, quercetin in apples and anthocyanins in strawberries. Fruits may also be classified by their antioxidant capacity using methods such as the Folin-Ciocalteu assay (expressed as total phenols content) or the Oxygen Radical Absorbance Capacity assay. An alternative system is based on the quantity and quality of antioxidants derived from phenols present in fruit, which is expressed as an index (PAOXI) ${ }^{(29)}$. Free and total phenol quality is measured by the ability of the fruit to inhibit the oxidation of LDL and VLDL induced by cupric ion. Using this indexing system, Vinson et al. ${ }^{(30)}$ evaluated the phenols present in twenty commonly consumed fruits in the American diet. They reported that among the twenty fruits tested, berries are the best source of polyphenol antioxidants, and therefore have the greatest likelihood of delivering an effect in vivo, since concentrations of fruit phenolic compounds in plasma are generally very low (1 $\mu \mathrm{M}$ or less). They also reported that fruits had significantly higher PAOXI values compared with vegetables. Whether higher PAOXI values of fruits translates to greater protection from chronic diseases compared with vegetables is uncertain.

\section{Fruit phenolic compounds: present intake}

Intake of phenolic compounds can range several fold depending on individual dietary patterns. Estimates of intake also rely on methods of assessment. Various estimates suggest American's consume $20 \mathrm{mg}$ of flavonoids a day ${ }^{(16)}$, based predominately on flavonol and flavone intake, and up to approximately $190 \mathrm{mg}$ daily ${ }^{(31)}$, based on intake of flavan3-ols, flavanones, flavonols, anthocyanidins, flavones and isoflavones. In a dataset of ninety-two students using $7 \mathrm{~d}$ food records, Cao et al. $(2009)^{(32)}$ reported mean flavonol (quercetin and kaempferol) intake of $28.55 \mathrm{mg} / \mathrm{d}$. Primary food sources included tea ${ }^{(16,31)}$, onions ${ }^{(16)}$, apples ${ }^{(16,32)}$, broccoli $^{(16)}$, citrus fruit juices ${ }^{(31)}$, wine ${ }^{(31)}$, potato ${ }^{(32)}$, celery ${ }^{(32)}$ and citrus fruits ${ }^{(16)}$. Flavonols and flavones from other identified fruits/fruit sources, namely blueberries and strawberries, have been reported low, $<1 \%(16)$. In a seven countries report by Hertog et al. ${ }^{(33)}$, flavonoid intake ranged from $2.6 \mathrm{mg} / \mathrm{d}$ in West Finland to $68.2 \mathrm{mg} / \mathrm{d}$ in Ushibuka, Japan $^{(33)}$. Consistent with the US reports, quercetin contributes most of the flavonoid intake, contributing $>50 \%$ in most countries and up to $100 \%$ in West Finland ${ }^{(33)}$. In our own estimates of dietary flavonoids intake using the United States Department of Agriculture Flavonoid database $2 \cdot 1^{(34)}$ and using dietary food intake records from a recently completed study in our lab (unpublished results), we found that the diets of pre- and post-menopausal women in the greater Chicago, IL, area contained anywhere from $<1 \mathrm{mg} / \mathrm{d}$ to approximately $400 \mathrm{mg} / \mathrm{d}$; or 0-292 mg/4184 kJ. Flavan-3-ol from tea intake contributed greatly to the higher dietary flavonoid intakes. Dietary flavonoids intake from meal plans taken from the dietary approaches to stop hypertension diet studies $^{(12}$ ) were estimated at approximately $4.6 \mathrm{mg} / 4184 \mathrm{~kJ}$ for the control diet and approximately $13.7 \mathrm{mg} / 1000 \mathrm{kcal}$ for the dietary approaches to stop hypertension diet. 
These estimates were calculated using the 2003 version of the United States Department of Agriculture Flavonoids database (version 2.0), of which only approximately $60 \%$ of foods were found in the database. Additionally, the dietary approaches to stop hypertension diet was designed to target the action of non-flavonoid dietary constituents ( $\mathrm{K}, \mathrm{Ca}$ and $\mathrm{Mg}$ ), but emphasised fruit and vegetable intake. Hence, dietary flavonoids intake, including classes of flavonoids, can vary immensely depending on food choice. An important additional consideration is timing of intake of dietary flavonoid and non-flavonoid phenolic compounds. Minimising the consequences of energy-dense meals may be an important feature of dietary phenolic antioxidant compounds on human health.

\section{Fruit phenolic compounds: Mechanisms of action for health benefit}

Fruit phenolic compounds may provide benefit to human subjects via several mechanisms ${ }^{(35)}$. The best-described and most well-known mechanism is through their antioxidant properties and modulation of biological oxidative stress to prevent damage to cellular lipids, proteins and DNA. Directly, they may scavenge superoxide and other reactive oxygen species (ROS) such as hydroxyl and peroxy radicals. For example, from a thermodynamic standpoint, the chemical nature of flavonols lends them favourable to effectively scavenge superoxide anions, singlet oxygen and lipid peroxy radicals ${ }^{(36)}$. Indirectly, some flavonoids may spare/recycle endogenous antioxidant (e.g. glutathione, urate, vitamin $\mathrm{E}$ and vitamin C) and selected flavonoids, such as catechins and quercetin, may chelate redox active metals, such as $\mathrm{Fe}$ and $\mathrm{Cu}$, thereby removing a causal factor in free radical generation $^{(36-38)}$. Flavonoid-metal complexes have also been reported to mimic superoxide dismutase activity providing another mechanism of 'antioxidant defence' benefit ${ }^{(39)}$. However, the biological relevance of these described healthpromoting mechanisms of flavonoid, such as free radical scavenging and metal chelation is questioned due to a kinetically unfavourable situation with respect to endogenous compounds such as glutathione, urate, vitamin $\mathrm{C}$ and a panoply of endogenous metal chelators that exist in plasma and tissues at much higher concentrations than flavonoid compounds $\left(\mu \mathrm{M}-\mathrm{mM}\right.$ v. nM-lower $\mu \mathrm{M}$, respectively) ${ }^{(36)}$. Similarly, questions have been raised about fruit-derived phenolics on the sparing or recycling of certain endogenous antioxidant defence compounds. Fruits deliver fructose along with phenolic compounds and some of the actions often ascribed to phenolics may be due to fructose. Fructose has been known for years to increase plasma urate levels through fructokinase-mediated metabolism to fructose 1-phosphate ${ }^{(40,41)}$. An increase in urate concentrations commensurate with increased plasma antioxidant capacity, which has been reported after strawberry, spinach and apple consumption $^{(42,43)}$. Further, Lottito \& Frei ${ }^{(43)}$ reported parallel increases in urate and plasma antioxidant capacity after human volunteers consumed red delicious apples or fructose solution, each providing approximately $64 \mathrm{~g}$ fructose. Future studies on the antioxidant effects of flavonoid-rich foods should consider the effects of other non-phenolic contributors, such as the content of fructose, sucrose and sorbitol.
Indirect mechanisms of flavonoids involving lipid-flavonoid or protein-flavonoid interactions may be considered from a different perspective. Interactions requiring higher molecular specificity can withstand lower availability of substrate. Hence, alterations in membrane and protein function that involve lipid-flavonoid or protein-flavonoid interaction can happen at very low flavonoid concentrations and have significant biological effects at flavonoid concentrations attainable through diet. Stimulating endogenous antioxidant defence systems (e.g. superoxide dismutase and glutathione peroxidase) and/or inhibiting enzymes that generate large amounts of ROS such as xanthine oxidase and $\mathrm{NAD}(\mathrm{P}) \mathrm{H}$ oxidase are examples of 'indirect' antioxidant effects derived from protein-flavonoid interactions. Inhibiting absorption of already oxidised products, such as lipid hydroxyperoxides ${ }^{(8,44)}$, may be yet another mechanism of benefit by some phenolic compounds.

Over the last several years, polyphenolic compounds have been studied for their action in cellular signalling: modifying pathways of inflammation, insulin action, platelet function and vascular relaxation ${ }^{(35)}$. For example, it is known that oxidants increase pro-inflammatory transcription factor $\mathrm{NF}-\kappa \mathrm{B}$, whereas antioxidants such as pyrrolidine dithiocarbamate and $N$-acetyl cysteine inhibit NF- $\mathrm{B}$ activation ${ }^{(45)}$. Polyphenolic compounds from red wine have been shown to modulate $\mathrm{NF}-\kappa \mathrm{B}$ activation, suggesting a redox-mediated action of red wine polyphenols on inflammatory pathways ${ }^{(46)}$. Extracts of strawberry rich in anthocyanins have been shown to attenuate oxidative stress $\left(\mathrm{H}_{2} \mathrm{O}_{2}\right)$-induced impairment of insulin signalling by restoring insulin receptor substrate-1 activation in human skeletal muscle cells ${ }^{(47)}$, an effect also shown in hepatoma cells with tea-derived (-)-epigallacatechin3 -gallate ${ }^{(48)}$. Nitric oxide (NO)-stimulated endotheliumdependent relaxation by red wine, grape seed extract (GSE) and strawberries is due to activation of the protein kinase $B$ (Akt)/phosphatidylinositol-3 kinase pathway, also well known for its regulation by cellular redox status ${ }^{(49-51)}$. Overall, phenolic compounds found in plant foods, including fruits, have multiple paths for benefiting human health, most notably, through their actions as antioxidants and modifying cellular events. Their specific actions are likely to be dependent on the composition and time course of compound-/metabolites appearing in plasma ${ }^{(26,52,53)}$. Continued advancement in technology and investment in research will help to elucidate these details.

\section{The postprandial (fed) state}

The postprandial state is a pro-oxidant state. The postprandial period is a time of active oxidative metabolism and formation of ROS. An imbalance between oxidant generation and antioxidant defence in favour of oxidants potentially leading to biological dysfunction and/or damage is referred to as oxidative stress. Postprandial hyperlipidaemia and hyperglycaemia induced by meals rich in lipids and carbohydrate induces a relative oxidative stress that is exaggerated and prolonged in individuals who are obese or diabetic ${ }^{(5,7,54,55)}$, highlighting the importance of insulin sensitivity. Postprandial oxidative stress is typically accompanied by postprandial inflammation and impaired endothelial function ${ }^{(56)}$. Postprandial hyperlipidaemia and hyperglycaemia are risk factors for 
cardio-metabolic disease, which is strongly associated with oxidative imbalance ${ }^{(4,57-59)}$. Therefore, consuming fruits rich in phenolic compounds with meals may have several advantages in the postprandial state, first and foremost, through their inherent antioxidant properties and potential to modulate cellular reductive-oxidative (redox) balance.

Several studies have shown that the phenolic compounds in fruit are bioavailable and can increase the antioxidant capacity of the plasma acutely and after long-term consumption ${ }^{(26,60,61)}$. However, this is not apparent in all studies ${ }^{(62-66)}$ and might be explained in part by the methods used to assess antioxidant capacity, experimental approach, dose, type of fruit and matrix, among other complex factors. Nonetheless, critical to the conclusion is the need to demonstrate changes in biological endpoints that indicate health and/or are involved in the pathology of disease. In light of the importance of postprandial glucose and lipid metabolism in health and disease risk, the effects of fruit on these parameters have been collated.

\section{Postprandial glycaemia and insulinaemia}

Postprandial hyperglycaemia is widely recognised as producing oxidative stress and is associated with exacerbating a number of disease and disease-related conditions, such as diabetes and atherosclerotic CVD, metabolic syndrome, hypertension and obesity ${ }^{(57-59)}$ as depicted in Fig. 1. Hyperglycaemia is associated with the generation of ROS and reactive nitrogen species, respectively, arising from several intracellular sources. In normal physiology, antioxidant defence systems balance ROS/reactive nitrogen species. When these systems are overwhelmed, excess ROS/reactive nitrogen species alters redox balance increasing the activation of pro-inflammatory pathways (e.g. NF-кB), impairing cellular signalling (e.g. insulin signalling) and causing irreversible modifications of cellular and non-cellular components ${ }^{(67)}$. Hyperglycaemia can promote non-enzymatic glycation of proteins (Fig. 1), such as $\mathrm{LDL}^{(68)}$, and can increase the susceptibility of LDL to oxidation ${ }^{(69,70)}$. Oxidised LDL is implicated in the initiation, progression and complication of atherosclerotic $\mathrm{CVD}^{(71,72)}$. Hence, strategies to modify postprandial glycaemia to favour a balanced system are warranted.

The glycaemic response to a meal is driven by preabsorptive and postabsorptive factors, including characteristics of the meal (dose and digestibility of carbohydrate, co-existing dietary factors and food matrix), alimentary metabolism and a variety of associated neuroendocrine responses, most notably the secretion and action of insulin to facilitate glucose clearance from the blood. The ability of fruits, based on their inherent phenolic composition, to favourably augment glucose metabolism would likely be through one of these factors. Interference with glucose absorption and/or modifying insulin-mediated glucose metabolism are two probable mechanisms; the latter having relevance in both glucose and lipid metabolisms and linking the antioxidant properties of fruit phenolics with cellular redox-sensitive pathways.

Few studies have examined the relationship between fruit phenolic compounds and postprandial glycaemia. Ten human

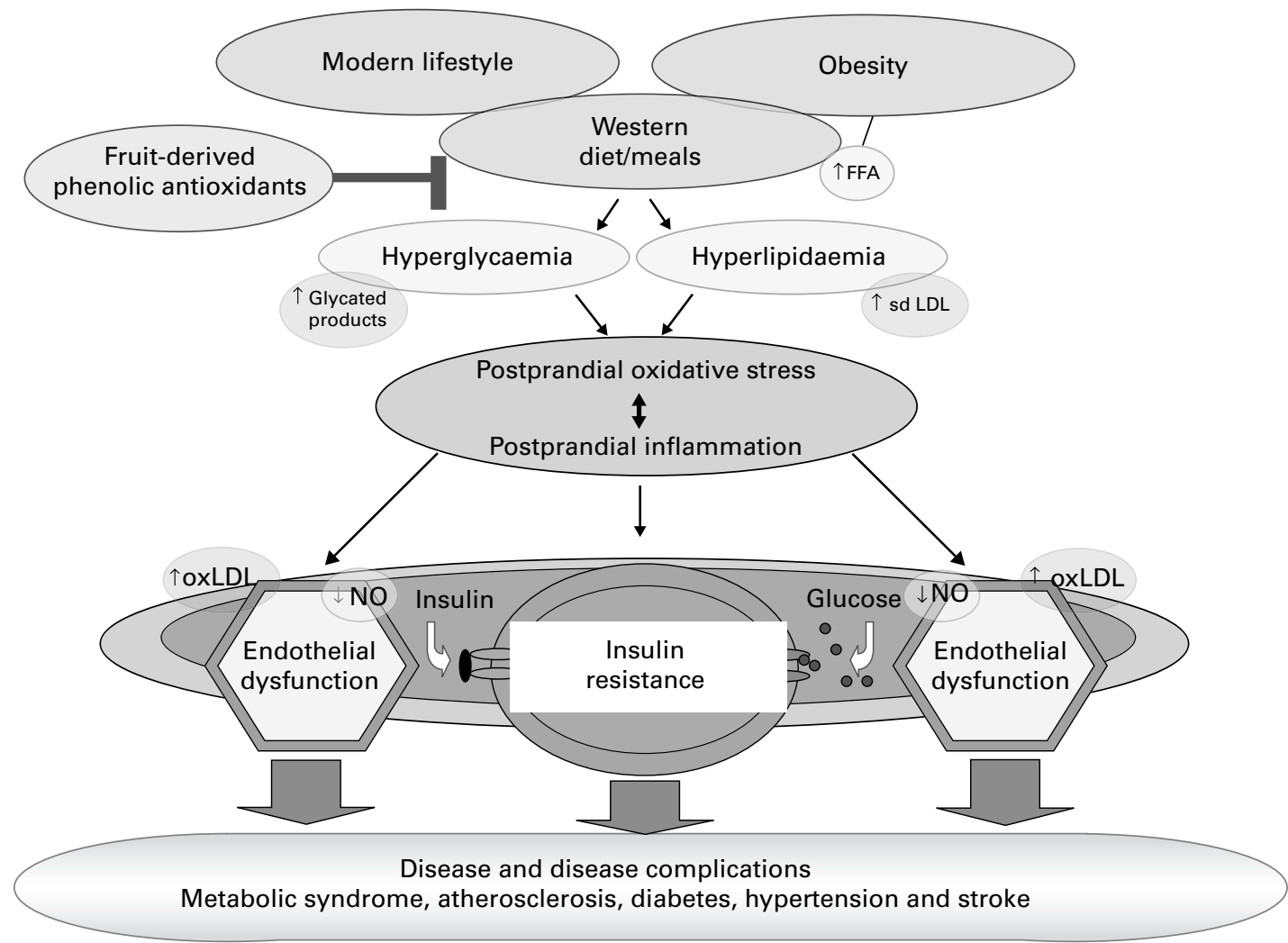

Fig. 1. Postprandial dysmetabolic-induced oxidative stress and possible mechanisms for fruit phenolic action. FFA, free fatty acid; sd LDL, small dense LDL; ox LDL, oxidised LDL; NO, nitric oxide. 
Table 1. Clinical trials examining postprandial glucose and insulin responses after fruit-associated polyphenolic treatments

\begin{tabular}{|c|c|c|c|c|c|c|c|c|c|c|}
\hline References & Study design & $n$ & Subjects* & Fruit & Delivery† & Treatments & Dose & $\begin{array}{l}\text { Glucose } \\
\text { findings }\end{array}$ & $\begin{array}{l}\text { Insulin } \\
\text { findings }\end{array}$ & $P$ \\
\hline $\begin{array}{l}\text { Ceriello } \\
\text { et al. }^{(54)}\end{array}$ & $\begin{array}{l}\text { Within subject } \\
\text { crossover } \\
3 t \times t \\
0-3 \mathrm{~h}\end{array}$ & 20 & $\begin{array}{l}\text { T2DM } \\
\text { M, F }\end{array}$ & RW & Beverage + meal & $\begin{array}{l}\text { Meal alone } \\
\text { RW alone RW + meal } \\
\text { Meal: } 30 \% \text { fat } 2510.4 \mathrm{~kJ}\end{array}$ & $\begin{array}{l}300 \mathrm{ml} \text { total phenols, } \\
\text { not specified }\end{array}$ & Gluc- & Ins- & NS, NS \\
\hline $\begin{array}{l}\text { Natella } \\
\quad \text { et al. }\end{array}$ & $\begin{array}{l}\text { Within subject } \\
\text { crossover } \\
2 t \times t \\
0-3 \mathrm{~h}\end{array}$ & 6 & $\begin{array}{l}\text { Healthy } \\
\text { M }\end{array}$ & RW & Beverage + meal & $\begin{array}{r}\text { RW EtOH Meal: } 24 \% \\
\text { fat } 40 \% \text { RMR } \times 1.5\end{array}$ & $\begin{array}{l}400 \mathrm{ml} 3 \cdot 2 \mathrm{~g} / \mathrm{l} \\
\text { total phenols }\end{array}$ & Gluc- & & NS, NS \\
\hline $\begin{array}{l}\text { Naissides } \\
\text { et al. }^{(78)}\end{array}$ & $\begin{array}{l}\text { Within subject } \\
\text { crossover } \\
3 t \times t \\
0-6 \mathrm{~h}\end{array}$ & 17 & $\begin{array}{l}\text { Post-M } \\
\text { dyslip } \\
\text { OW } \\
\text { F }\end{array}$ & RW & Beverage + meal & $\begin{array}{l}\text { RW RW-de-alco water } \\
\text { Meal: } 53 \% \text { fat } 1882 \cdot 8 \mathrm{~kJ}\end{array}$ & $\begin{array}{l}400 \mathrm{ml} 2 \cdot 2 \mathrm{~g} / \mathrm{l} \\
\text { total phenols }\end{array}$ & Gluc- & $\operatorname{lns} \uparrow$ & $\begin{array}{l}\text { Gluc, NS } \\
\text { Ins, } P<0.05 \\
\text { RW v. water }\end{array}$ \\
\hline $\begin{array}{l}\mathrm{Pal} \\
\quad \text { et al. }\end{array}$ & $\begin{array}{l}\text { Within subject } \\
\text { crossover } \\
3 t \times t \\
0-6 \mathrm{~h}\end{array}$ & 8 & $\begin{array}{l}\text { Post-M } \\
\text { dyslip } \\
\text { OW } \\
\text { F }\end{array}$ & RW & Beverage + meal & $\begin{array}{l}\text { RW RW-de-alco water } \\
\text { Meal: not specified } \neq\end{array}$ & $\begin{array}{l}400 \mathrm{ml} 2 \cdot 2 \mathrm{~g} / \mathrm{l} \\
\text { total phenols }\end{array}$ & Gluc- & Ins- & NS, NS \\
\hline $\begin{array}{l}\text { Kay \& } \\
\text { Colub }^{(75)}\end{array}$ & $\begin{array}{l}\text { Within-subject } \\
\text { crossover } \\
2 t \times t \\
0-4 \mathrm{~h}\end{array}$ & 8 & $\begin{array}{l}\text { Healthy } \\
\text { M }\end{array}$ & WBB & Beverage + meal & $\begin{array}{l}\text { WBB Phenol-free Pbo } \\
\text { Meal: } 49 \% \text { fat } 3568.952 \mathrm{~kJ}\end{array}$ & $\begin{array}{l}100 \mathrm{~g} \text { FD powder } \\
14.7 \mathrm{mmol} \mathrm{TE}\end{array}$ & Gluc $\uparrow$ & & $\begin{array}{l}P<0.05 \\
\text { WBB v. Pbo } \\
\text { at } 3 \text { and } 4 \mathrm{~h}\end{array}$ \\
\hline $\begin{array}{l}\text { Cao } \\
\text { et al. }\end{array}$ & $\begin{array}{l}\text { Within subject } \\
\text { crossover } \\
5 t \times t \\
0-4 \mathrm{~h} \S, 11 \mathrm{~h}\end{array}$ & 8 & $\begin{array}{l}\text { Healthy } \\
\text { elderly } \\
\text { F }\end{array}$ & RW & Beverage formula & $\begin{array}{l}\text { RW Str spinach Vit C ctrl bev } \\
\text { Beverage: } 36 \% \text { fat } 1046 \mathrm{~kJ}\end{array}$ & $300 \mathrm{ml} 3.7 \mathrm{mmol}$ TE & Gluc- & & NS \\
\hline $\begin{array}{l}\text { Cao } \\
\text { et al. }\end{array}$ & $\begin{array}{l}\text { Within subject } \\
\text { crossover } \\
5 t \times t \\
0-4 \mathrm{~h} \S, 11 \mathrm{~h}\end{array}$ & 8 & $\begin{array}{l}\text { Healthy } \\
\text { elderly } \\
\text { F }\end{array}$ & Str & Beverage formula & $\begin{array}{l}\text { RW Str Spinach Vit C ctrl bev } \\
\text { Beverage: } 36 \% \text { fat } 1046 \mathrm{~kJ}\end{array}$ & $240 \mathrm{~g} 3.7 \mathrm{mmol}$ TE & Gluc- & & NS \\
\hline $\begin{array}{l}\text { Vinson } \\
\quad \text { et al. }\end{array}$ & $\begin{array}{l}\text { Within subject } \\
\text { crossover } \\
2 t \times t \\
0-4 \mathrm{~h} \S, 7 \mathrm{~h}\end{array}$ & 10 & $\begin{array}{l}\mathrm{OW} \\
\mathrm{M}, \mathrm{F}\end{array}$ & CB & $\mathrm{J}+$ Vit C (80 mg) & $\begin{array}{l}\text { CBJ + Vit C J Pbo + Vit C } \\
\text { Beverage: } 627 \cdot 6 \mathrm{~kJ}\end{array}$ & $\begin{array}{l}240 \mathrm{ml} 175 \mathrm{mg} \\
\text { total phenols }\end{array}$ & Gluc- & & NS \\
\hline $\begin{array}{l}\text { Wilson } \\
\quad \text { et al. }\end{array}$ & $\begin{array}{l}\text { Parallel } \\
6 t \times t \\
0-3 \mathrm{~h}\end{array}$ & 187 & $\begin{array}{l}\text { Healthy } \\
\text { M, F }\end{array}$ & CB & $\begin{array}{l}\text { J LoJ (158.992 kJ) } \\
\text { NmJ (1171.52 kJ) }\end{array}$ & $\begin{array}{l}\text { Lo CB J Nm CB J LoHFCS J } \\
\text { NmHFCS J water nothing } \\
\text { Beverage: } 158.992 \text { or } \\
1171.52 \mathrm{~kJ}\end{array}$ & $\begin{array}{l}480 \mathrm{ml} / 70 \mathrm{~kg} \text { total } \\
\text { phenols, not specified }\end{array}$ & $\begin{array}{l}\text { AUC } \\
\text { Gluc- }\end{array}$ & $\begin{array}{l}\text { AUC } \\
\text { Ins- }\end{array}$ & NS, NS \\
\hline $\begin{array}{l}\text { Erdmann } \\
\quad \text { et al. }\end{array}$ & $\begin{array}{l}\text { Within subject } \\
\text { crossover } \\
5 t \times t \\
0-4 \mathrm{~h} \S, 5 \mathrm{~h}\end{array}$ & 14 & $\begin{array}{l}\text { Healthy } \\
\text { M, F }\end{array}$ & $\begin{array}{l}\text { Apple, } \\
\text { kiwi, } \\
\text { banana }\end{array}$ & Fresh fruit & $\begin{array}{l}\text { Fat meal protein meal } \\
\text { carb meal fruit meal } \\
\text { veg meal }\end{array}$ & Mean $(693 \mathrm{~g})$ & Gluc- & Ins- & NS, NS \\
\hline
\end{tabular}


trials were selected for the review (Table 1). These trials met criteria that included a minimum $2 \mathrm{~h}$ postprandial assessment of plasma glucose and included adequate controls or comparative data to evaluate the effect of the studied fruit on glycaemia. Criteria for delivery of fruit with a meal was desired, but was not mandatory given the small number of published trials. Cranberry juice ${ }^{(73,74)}$, wild blueberry ${ }^{(75)}$, strawberry $^{(42)}$ and a fruit meal of banana, kiwi and apple ${ }^{(76)}$ were the subject of five trials. Five additional trials were included that tested red wine or components of red wine with a meal ${ }^{(54,77-79)}$ or was a comparator in another study ${ }^{(42)}$. Of these ten trials, six trials provided fruit as a beverage or in a beverage formula with meals ${ }^{(54,42,75,77-79)}$. As shown in Table 1, no remarkable effects on plasma glucose were reported overall. Only one trial reported a possible action in modifying glucose metabolism ${ }^{(73)}$. In the trial by Wilson et $a l .{ }^{(73)}$, incremental area under the glucose curve after normal energy cranberry and energy control drinks was not different; however, the pattern of glycaemia was modified in the cranberry-containing drink, suggesting delayed absorption or altered distribution of glucose to insulin-sensitive tissues. Quercetin, a major phenolic compound in cranberry, has been shown to inhibit gastric uptake of glucose in a porcine model $^{(80)}$. Quercetin and myricetin have been demonstrated to inhibit GLUT-4-mediated uptake by adipocytes ${ }^{(81)}$; whereas insulin-sensitising actions of quercetin in liver and muscle have been reported in fructose-fed rat model of insulin resistance $^{(82)}$. Based on this limited evidence, no specific claims can be made relative to postprandial glucose control and cranberry or its associated phenolic compounds. Likewise, no evidence supports a glucose-lowering effect of consuming polyphenolic-rich fruits or beverages with meals. One trial reported an increase in postprandial glucose with wild blueberry consumption delivered in a beverage with a high-fat meal ${ }^{(75)}$. The elevated glucose may be due to differences in mono-and di-saccharide content of treatments and/or the higher fibre content of the wild blueberry altering glucose absorption and metabolism. Insulin concentrations or other metabolic indices were not reported to help explain the results.

The postprandial insulin response is critical in the management of postprandial glucose metabolism as well as lipid and lipoprotein metabolisms. Insulin signalling is sensitive to cellular redox balance ${ }^{(83)}$, suggesting that fruits rich in antioxidant compounds could beneficially impact nutrient metabolism through improved or enhanced insulin signalling in insulin-sensitive tissues. Five of the ten trials identified reported changes in postprandial insulin concentrations. Four reported no differences among treatments ${ }^{(54,73,76,79)}$ and one $^{(78)}$ reported elevated postprandial insulin concentrations after red wine consumption compared with dealcoholised red wine or water with a standardised meal of $75 \mathrm{~g}$ cheese and $50 \mathrm{~g}$ fat-free crackers in postmenopausal women. Recent work in our lab suggests that a strawberry-based drink delivering approximately $126 \mathrm{mg}$ total flavonoids (approximately $82 \mathrm{mg}$ anthocyanins) consumed with a moderate fat/carbohydrate meal reduces the postprandial insulin response in overweight men and women compared with when the same meal is consumed with a placebo (non-flavonoid containing) drink $^{(84)}$. No differences in postprandial glucose concentrations were observed between treatment conditions. These data suggest reduced insulin requirement to achieve glucose homoeostasis, supporting improved postprandial insulin sensitivity, an effect that appears to be mediated through redox-sensitive insulin signalling pathways ${ }^{(82,84)}$. More studies are needed to elucidate the potential effects of fruit phenolics on insulin action in human subjects.

\section{Postprandial lipaemia}

Elevated postprandial TAG are associated with increased risk for the development and progression of atherosclerotic $\mathrm{CVD}^{(85)}$ and can be more discriminating than fasting concentrations in assessing high-risk atherosclerotic conditions ${ }^{(86)}$. Fasting and postprandial hyperlipidaemia is apparent in individuals with obesity, diabetes mellitus and metabolic syndrome $^{(9,85,87)}$. These conditions are also characterised by elevated NEFA, low-grade inflammation and impaired insulin sensitivity ${ }^{(4)}$, all of which promote and exacerbate disturbances in lipid metabolism. It is important to note that inflammatory mediators alone can trigger insulin resistance in cells, in the absence of obesity and other factors ${ }^{(88)}$. For example, ingestion of a high-fat or glucose challenge meal provokes an acute inflammatory response ${ }^{(83,89-92)}$. Excessive intake of energy-dense, nutrient-poor foods provides potent substrate for inducing postprandial inflammation. Several lines of evidence, including work in our laboratory, suggest that the acute response arises from induction of oxidative stress and stimulated inflammatory pathways leading to reduced insulin sensitivity ${ }^{(84,88-92)}$ (Fig. 1). Under these conditions, lipaemia is magnified and the relative composition of all lipoproteins changes supporting an atherogenic state of the plasma. VLDL remnants are cholesterol ester enriched and in exchange, HDL become TAG rich and cholesterol depleted, which after further modification leads to the dissociation of the structurally important protein apo A-I, resulting in clearance and reduced HDL. Through a similar process, LDL become small and more susceptible to oxidation $^{(4,87)}$. Oxidised LDL are proposed to play a causative role in early atherogenesis through their ability to up-regulate scavenger receptors on activated monocytes, transforming them into macrophages, eventually leading to foam cell formation ${ }^{(93)}$.

Another aspect of postprandial lipaemia is endothelial dysfunction (Fig. 1). Many endothelial-derived factors, of which NO plays a central role, regulate vasomotion, permeability, proliferation and smooth muscle cell migration. Elevated TAG and NEFA are associated with reduced NO, a result that appears related to oxidative stress generation ${ }^{(9,56)}$. The oxidative imbalance results in reduced endothelial NO synthase activity and peroxynitrile generation and activation/

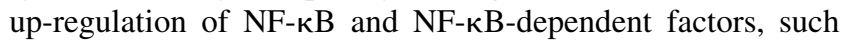
as monocyte chemoattractant protein-1, cellular adhesion molecules (e.g. intercellular adhesion molecule and vascular adhesion molecule), cytokines, growth factors and metalloproteinases, as well as pro-thrombotic factors including increased plasminogen activator inhibitor- 1 and tissue factor to name a few ${ }^{(94)}$. Overall, the lipaemia-induced oxidative stress promotes a pro-inflammatory, pro-thrombotic unstable atherogenic environment. In principle, preventing or decreasing the postprandial-induced oxidative stress or the associated inflammatory response should interrupt the metabolic-oxidative-inflammatory circle providing balance to the system and resistance to pathology. This may be one 
mechanism by which eating fruits and vegetables regularly favour reduced disease risk.

Focused on fruits and their inherent phenolic quality to impart an action on postprandial lipaemia or associated events, fifteen trials using the postprandial testing paradigm were reviewed and are listed in Table 2. Changes in postprandial TAG were reported in twelve trials, of which one of the twelve trials ${ }^{(79)}$ reported changes in plasma TAG and chylomicron (B-48) concentrations postmeal and another ${ }^{(46)}$ reported changes in TAG, chylomicron and VLDL concentrations postmeal. Overall, seven trials reported no specific advantage on postprandial TAG management when consuming wild blueberry $^{(75,95)}$, cultivated blueberry ${ }^{(96)}$ or red wine ${ }^{(54,77,79)}$ or $\mathrm{GSE}^{(98)}$ with a high/moderate fat meal (or whole milk $\left.^{(96)}\right)$. Serafini et al. ${ }^{(96)}$ reported a $6 \%$ increase in total cholesterol at $5 \mathrm{~h}$ after consumption of $200 \mathrm{~g}$ blueberry with whole milk compared with the same dose of fruit with water; however, three other trials showed no changes in postprandial total cholesterol, LDL or HDL ${ }^{(75,77,97)}$. Three trials reported decreased postprandial TAG after consuming strawberry $^{(10)}$, apple procyanidins $(600 \mathrm{mg} \text { capsule })^{(98)}$ and cranberry juice ${ }^{(74)}$ with moderate fat, high fat or no fat meals, respectively. The TAG-lowering effect of fruits or their active constituents may have been by inhibition of pancreatic lipase activity ${ }^{(98)}$, reduced dietary TAG absorption $^{(79)}$ and/or by enhanced clearance, possibly through antioxidant-mediated enhanced postprandial insulin sensitivity ${ }^{(99)}$. Two trials reported elevated TAG when drinking red wine with a fat-enriched meal ${ }^{(78,46)}$. Increased postprandial TAG was evident after consuming red wine with alcohol compared with dealcoholised red wine or water ${ }^{(78)}$ or after consuming a low-alcohol red wine or no wine ${ }^{(46)}$, respectively, despite differences in trial population (postmenopausal dyslipidaemic women $v$. healthy young men and women). Elevation of VLDL indicates alcohol-induced stimulated hepatic lipogenesis with red wine ${ }^{(46)}$; however, when alcohol (vodka) was controlled and the ratio of sugar to red wine alcohol varied (increased) at an equivalent energy level, VLDL was not increased compared with no wine with the fatty meal. These data suggest a threshold effect of alcohol plus sugar in stimulating hepatic lipogenesis or modifying clearance of VLDL. In either case, excess or prolonged circulation of TAG-rich lipoproteins, like VLDL, can be unfavourable, as discussed earlier. Interestingly, despite elevated TAG and VLDL after red wine consumption with a fat-enriched breakfast, Blanco-Colio et al. ${ }^{(46)}$ reported reduced NF-кB activation in cultured mononuclear cells in a time-dependent manner that was not evident in the no-wine or vodka conditions. Hence, components of red wine, presumably phenolic compounds, provided a relative protection from the potentially deleterious effects of the associated postprandial hyperlipidaemia.

Excessive metabolic substrate and dysregulated lipid (and carbohydrate) metabolism exposes cells to an overload of nutrients, generating a relative imbalance of ROS/reactive nitrogen species to antioxidant defences triggering a number of endogenous cellular responses that support and perpetuate the imbalanced state. The antioxidant properties of phenolic compounds in fruits and their contribution to the total antioxidant defence system are likely the underlying mechanism by which fruit consumption impart their greatest benefit. In the case of lipid metabolism, the protection of LDL from oxidation is a critical matter. Elevated plasma concentrations of oxidised LDL are apparent in patients with CHD and diabetes and predict future risk of CHD events in apparently healthy men ${ }^{(100-103)}$. Several in vitro and ex vivo investigations (after feeding trials of days to weeks with fruit, fruit juice and wine) have demonstrated a relationship between increasing plasma antioxidant status and decreasing the susceptibility of LDL to oxidation ${ }^{(104-109)}$. In contrast, few investigations have examined acute protection of LDL, such as in a postprandial challenge paradigm. Postprandial LDL are more susceptible to oxidation than fasting $\mathrm{LDL}^{(110)}$ and postprandial LDL have been shown to accumulate more readily in activated macrophages than LDL derived from fasting samples ${ }^{(71,110)}$. The mechanism by which LDL become oxidised are not completely clear. Absorption of dietary-derived lipid hydroperoxides that incorporate into lipoproteins and act as initiators for further lipoprotein oxidative modification is one possibility ${ }^{(8)}$. The typical intake of lipid hydroperoxides in a fat-rich western diet has been estimated as $1.5 \mathrm{mmol} / \mathrm{d}^{(111)}$. Consumption of polyphenols with a highfat meal has been shown to decrease plasma lipid hydroperoxides. Natella et al. ${ }^{(97)}$ showed in eight healthy men who consumed a standard 'Milanese' style meat and potatoes meal with (active) and without (placebo) $300 \mathrm{mg}$ GSE that plasma lipid hydroperoxides were 1.5 -fold higher in the placebo meal $1 \mathrm{~h}$ after the meal compared with the GSE active meal. Correspondingly, plasma antioxidant capacity was higher in the active GSE meal and resistance to LDL oxidation was enhanced, although statistical significance was not achieved between placebo and GSE active meals, a factor possibly due to timing of assessment and small sample size.

Circulating LDL is subject to oxidation in a pro-oxidative environment (postprandial state) when defences are inadequate. Acute protection may require direct association of antioxidant compounds with lipoproteins and/or activation of or preservation of the HDL-associated paraoxonase $1^{(112)}$. $\alpha$-Tocopherol is a well-known lipid-soluble antioxidant present in LDL. Previous work has shown that dietary phenolic compounds can bind human $\mathrm{LDL}^{(113)}$. Phenolic compounds that bind LDL are likely to provide a relative protection of LDL from ROS through their peroxylscavenging activity or by structural modification resulting in in vivo resistance to oxidation ${ }^{(114,115)}$. Bound polyphenols may also spare losses of endogenous antioxidants, like $\alpha$-tocopherol ${ }^{(77)}$.

Present therapeutic strategies in CVD target improving serum cholesterol, generally LDL cholesterol, as assessed by fasting total and LDL concentrations. Because oxidised LDL is an early initiator and propagator of atherosclerosis, there may be merit in strategies that target protection of LDL from oxidation during the postabsorptive period. Trials with vitamin supplements such as vitamin $\mathrm{E}$, vitamin $\mathrm{C}$ and $\beta$-carotene have been disappointing, possibly because they can act as pro-oxidants as well as antioxidants ${ }^{(112)}$. Longterm supplementation with polyphenolic compounds or polyphenolic-rich fruits on the susceptibility of fasting LDL has been disparate. Timing of intake (with or without a meal) may be one explanation for whether a favourable outcome will be achieved. Table 2 represents the few studies identified that measured oxidised LDL in plasma/serum after a meal that 


\begin{tabular}{|c|c|c|c|c|c|c|c|c|c|c|c|}
\hline References & Study design & $n$ & Subjects ${ }^{*}$ & Fruit & Delivery $\dagger$ & Treatments & Dose & $\begin{array}{l}\text { TAG } \\
\text { findings }\end{array}$ & $\begin{array}{l}\text { LDLox } \\
\text { findings }\end{array}$ & $\begin{array}{l}\text { Plasma AC } \\
\text { with method }\end{array}$ & $P$ \\
\hline $\begin{array}{l}\text { Ceriello } \\
\quad \text { et al. }\end{array}$ & $\begin{array}{l}\text { Within subject } \\
\text { crossover } \\
3 t \times t \\
0-3 \mathrm{~h}-\mathrm{TAG} \\
\text { 0-2h-LDLox }\end{array}$ & 20 & $\begin{array}{l}\text { T2DM } \\
\text { M, F }\end{array}$ & RW & $\begin{array}{l}\text { Beverage } \\
\quad+\text { meal }\end{array}$ & $\begin{array}{l}\text { Meal alone } \\
\text { RW alone } \\
\text { RW + meal } \\
\text { Meal: } 30 \% \text { fat } \\
2510.4 \mathrm{~kJ}\end{array}$ & $\begin{array}{l}300 \mathrm{ml} \\
\text { total phenols, } \\
\text { not specified }\end{array}$ & TAG- & LDLox- & $\begin{array}{l}\mathrm{AC} \uparrow \\
\wedge \mathrm{TRAP}\end{array}$ & $\begin{array}{l}\text { TAG, NS } \\
\text { LDLox, } \\
\text { NS AC } \\
\wedge P<0.001\end{array}$ \\
\hline $\begin{array}{l}\text { Natella } \\
\quad \text { et al. }{ }^{(77)}\end{array}$ & $\begin{array}{l}\text { Within subject } \\
\text { crossover } \\
2 t \times t \\
0-3 \mathrm{~h}\end{array}$ & 6 & $\begin{array}{l}\text { Healthy } \\
\text { M }\end{array}$ & RW & $\begin{array}{l}\text { Beverage } \\
\quad+\text { meal }\end{array}$ & $\begin{array}{l}\text { RW EtOH } \\
\text { Meal: } 24 \% \text { fat } \\
\text { kcal: } 40 \% \\
\text { RMR } \times 1.5\end{array}$ & $\begin{array}{l}400 \mathrm{ml} \\
3.2 \mathrm{~g} / \mathrm{l} \text { total } \\
\text { phenols }\end{array}$ & TAG- & LDLox $\downarrow$ & $\begin{array}{l}\mathrm{AC} \uparrow \\
\wedge \mathrm{TRAP}\end{array}$ & $\begin{array}{l}\text { TAG, NS } \\
\text { LDLox, } \\
P<0.05 \\
\text { AC } \\
\wedge P<0.003\end{array}$ \\
\hline $\begin{array}{l}\text { Naissides } \\
\text { et al. }{ }^{(78)}\end{array}$ & $\begin{array}{l}\text { Within subject } \\
\text { crossover } \\
3 t \times t \\
0-6 \mathrm{~h}\end{array}$ & 17 & $\begin{array}{l}\text { Post-M } \\
\text { dyslip } \\
\text { OW } \\
\text { F }\end{array}$ & RW & $\begin{array}{l}\text { Beverage } \\
\quad+\text { meal }\end{array}$ & $\begin{array}{l}\text { RW } \\
\text { RW-de-alco } \\
\text { water } \\
\text { Meal: } 53 \% \text { fat } \\
1882 \cdot 8 \mathrm{~kJ}\end{array}$ & $\begin{array}{l}400 \mathrm{ml} \\
2 \cdot 2 \mathrm{~g} / \mathrm{l} \text { total } \\
\text { phenols }\end{array}$ & $\mathrm{TAG} \uparrow$ & & & $\begin{array}{l}\text { Water v. RW } \\
P<0.02\end{array}$ \\
\hline Pal et al. ${ }^{(79)}$ & $\begin{array}{l}\text { Within subject } \\
\text { crossover } \\
3 t \times t \\
0-6 \mathrm{~h}\end{array}$ & 8 & $\begin{array}{l}\text { Post-M } \\
\text { dyslip } \\
\text { OW } \\
\text { F }\end{array}$ & RW & $\begin{array}{l}\text { Beverage } \\
\quad+\text { meal }\end{array}$ & $\begin{array}{l}\text { RW } \\
\text { RW-de-alco } \\
\text { water } \\
\text { Meal: not } \\
\text { specified } \neq\end{array}$ & $\begin{array}{l}400 \mathrm{ml} \\
2 \cdot 2 \mathrm{~g} / \mathrm{l} \text { total } \\
\text { phenols }\end{array}$ & $\begin{array}{l}\text { TAG- } \\
\mathrm{CM} \downarrow\end{array}$ & & & $\begin{array}{l}\text { TAG, NS } \\
\text { CM, } P<0.05 \\
\text { water } v \text {. } \\
\text { RW-de-alco }\end{array}$ \\
\hline $\begin{array}{l}\text { Blanco-Colio } \\
\text { et al. }\end{array}$ & $\begin{array}{l}\text { Within subject } \\
\text { crossover } \\
4 t \times t \\
0-9 \mathrm{~h}\end{array}$ & 16 & $\begin{array}{l}\text { Healthy } \\
\text { M, F }\end{array}$ & RW & $\begin{array}{l}\text { Beverage } \\
\quad+\text { meal }\end{array}$ & $\begin{array}{l}\text { RW, High dose } \\
\text { RW, low dose } \\
\text { Placebo } \\
\text { Vodka } \\
\text { Meal: } 57 \% \text { en fat } \\
2518.768 \mathrm{~kJ} / \mathrm{m}^{2}\end{array}$ & $\begin{array}{l}\mathrm{M}, 20 \text { or } 12 \mathrm{~g} / \mathrm{m}^{2} \\
\mathrm{~F}, 12 \text { or } 7.5 \mathrm{~g} / \mathrm{m}^{2}\end{array}$ & $\begin{array}{l}\text { TAG } \uparrow \\
\text { CM } \uparrow \\
\text { VLDL } \uparrow\end{array}$ & & & $\begin{array}{l}\text { TAG, } P<0.05 \\
\text { CM, } P<0.05 \\
\text { VLDL, } P<0.05\end{array}$ \\
\hline $\begin{array}{l}\text { Caccetta } \\
\text { et al. }\end{array}$ & $\begin{array}{l}\text { Within subject } \\
\text { crossover } \\
4 t \times t \\
0-4 \mathrm{~h}\end{array}$ & 12 & $\begin{array}{l}\text { Healthy } \\
\text { and OW } \\
\text { M }\end{array}$ & RW & $\begin{array}{l}\text { Beverage } \\
\quad+\text { meal }\end{array}$ & $\begin{array}{l}\text { RW } \\
\text { RW-de-alco } \\
\text { RW-phenol-strip } \\
\text { water } \\
\text { Meal: two } \\
\text { plain bagels }\end{array}$ & $\begin{array}{l}5 \mathrm{ml} / \mathrm{kg} \mathrm{BW} \\
2.0 \mathrm{~g} / \mathrm{l} \text { total } \\
\text { phenols }\end{array}$ & & LDLox- & & NS \\
\hline $\begin{array}{l}\text { Burton- } \\
\text { Freeman } \\
\text { et al. }{ }^{(10)}\end{array}$ & $\begin{array}{l}\text { Within subject } \\
\text { crossover } \\
2 t \times t \\
0-6 \mathrm{~h}\end{array}$ & 24 & $\begin{array}{l}\text { OW } \\
M, F\end{array}$ & Str & $\begin{array}{l}\text { Beverage } \\
\quad+\text { meal }\end{array}$ & $\begin{array}{l}\text { Str } \\
\text { Phenol-free Pbo } \\
\text { Meal: } 40 \% \text { fat } \\
2991.56 \mathrm{~kJ}\end{array}$ & $\begin{array}{l}10 \mathrm{~g} \text { FD powder } \\
126 \mathrm{mg} \text { total } \\
\text { phenols }\end{array}$ & $\mathrm{TAG} \downarrow$ & LDLox $\downarrow$ & & $\begin{array}{l}\text { TAG, } P<0.05 \\
\text { LDLox, } \\
P=0.008\end{array}$ \\
\hline $\begin{array}{l}\text { Kay \& } \\
\quad \text { Holub }^{(75)}\end{array}$ & $\begin{array}{l}\text { Within subject } \\
\text { crossover } \\
2 t \times t \\
0-4 \mathrm{~h}\end{array}$ & 8 & $\begin{array}{l}\text { Healthy } \\
\text { M }\end{array}$ & WBB & $\begin{array}{l}\text { Beverage } \\
\quad+\text { meal }\end{array}$ & $\begin{array}{l}\text { WBB } \\
\text { Phenol-free Pbo } \\
\text { Meal: } 49 \% \text { fat } \\
3568.952 \mathrm{~kJ}\end{array}$ & $\begin{array}{c}100 \mathrm{~g} \mathrm{FD} \text { powder } \\
14.7 \mathrm{mmol} \mathrm{TE}\end{array}$ & TAG- & & $\begin{array}{l}\mathrm{AC} \uparrow \\
\stackrel{\wedge}{\mathrm{ORAC}} \\
\text { MTAS/TEAC }\end{array}$ & $\begin{array}{l}\text { TAG, NS } \\
\text { AC at } 1 \mathrm{~h} \\
\wedge P=0.04 \\
M P=0.05\end{array}$ \\
\hline $\begin{array}{l}\text { Mazza } \\
\quad \text { et al. }\end{array}$ & $\begin{array}{l}\text { Within subject } \\
\text { crossover } \\
2 t \times t \\
0-4 \mathrm{~h}\end{array}$ & 5 & $\begin{array}{l}\text { Healthy } \\
\text { M }\end{array}$ & WBB & $\begin{array}{l}\text { Beverage } \\
\quad+\text { meal }\end{array}$ & $\begin{array}{l}\text { WBB } \\
\text { phenol-free Pbo } \\
\text { Meal: } 49 \% \text { fat } \\
3568.952 \mathrm{~kJ}\end{array}$ & $\begin{array}{c}100 \mathrm{~g} \mathrm{FD} \text { powder } \\
14.7 \mathrm{mmol} \mathrm{TE}\end{array}$ & TAG- & & $\begin{array}{l}\mathrm{AC} \uparrow \\
\stackrel{\wedge}{\wedge} \mathrm{ORAC} \\
\text { MTEAC }\end{array}$ & $\begin{array}{l}\text { TAG, NS } \\
\begin{array}{l}\text { AC at } 4 \mathrm{~h} \\
\wedge P=0.04 \\
M P=0.07(1 \mathrm{~h})\end{array}\end{array}$ \\
\hline $\begin{array}{l}\text { Natella } \\
\quad \text { et al. }\end{array}$ & $\begin{array}{l}\text { Within subject } \\
\text { crossover } \\
2 t \times t \\
0-3 \mathrm{~h}\end{array}$ & 8 & $\begin{array}{l}\text { Healthy } \\
\text { M }\end{array}$ & GSE & $\begin{array}{l}\text { Capsule } \\
\quad+\text { meal }\end{array}$ & $\begin{array}{l}\text { GSE, } 300 \mathrm{mg} \\
\text { Placebo } \\
\text { Meal: } 32 \% \text { fat } \\
\text { kcal: } 40 \% \\
\text { RMR } \times 1.5\end{array}$ & $300 \mathrm{mg}$ & TAG- & LDLox- & $\begin{array}{l}\text { AC } \uparrow \\
\wedge \text { TRAP } \\
\text { MProtein thiols } \\
\text { MHydroperoxides } \downarrow\end{array}$ & $\begin{array}{l}\text { TAG, NS } \\
\text { LDLox, NS } \\
\wedge P<0.05 \\
M P<0.05 \\
M P<0.05\end{array}$ \\
\hline
\end{tabular}


Table 2. Continued

\begin{tabular}{|c|c|c|c|c|c|c|c|c|c|c|c|}
\hline References & Study design & $n$ & Subjects* & Fruit & Delivery $\dagger$ & Treatments & Dose & $\begin{array}{l}\text { TAG } \\
\text { findings }\end{array}$ & $\begin{array}{l}\text { LDLox } \\
\text { findings }\end{array}$ & $\begin{array}{l}\text { Plasma AC } \\
\text { with method }\end{array}$ & $P$ \\
\hline $\begin{array}{r}\text { Sugiyama } \\
\text { et al. }{ }^{(98)}\end{array}$ & $\begin{array}{l}\text { Within subject } \\
\text { crossover } \\
3 \text { txt } 0-6 \mathrm{~h}\end{array}$ & 6 & $\begin{array}{l}\text { Healthy } \\
\text { M }\end{array}$ & AP & $\begin{array}{l}\text { Capsule } \\
\quad+\text { meal }\end{array}$ & $\begin{array}{l}\text { AP, } 600 \mathrm{mg} \\
\text { AP, } 1500 \mathrm{mg} \\
\text { Placebo } \\
\text { Meal: } 40 \mathrm{~g} \text { fat } \\
1673.6 \mathrm{~kJ}\end{array}$ & $\begin{array}{l}600 \mathrm{mg} \\
1500 \mathrm{mg} \\
0 \mathrm{mg}\end{array}$ & $\mathrm{TAG} \downarrow$ & & & $\begin{array}{l}0 \text { v. } 600 \mathrm{mg} \\
\quad P<0.05 \text { at } 6 \mathrm{~h}\end{array}$ \\
\hline $\begin{array}{l}\text { Vinson } \\
\quad \text { et al. }{ }^{(74)}\end{array}$ & $\begin{array}{l}\text { Within subject } \\
\text { crossover } \\
2 t \times t \\
0-4 \S, 7 \mathrm{~h}\end{array}$ & 10 & $\begin{array}{l}\text { OW } \\
\text { M, F }\end{array}$ & $\mathrm{CB}$ & $\begin{array}{r}\mathrm{J}+\text { Vit C } \\
(80 \mathrm{mg})\end{array}$ & $\begin{array}{l}\text { CBJ + Vit C } \\
\text { J Pbo + Vit C } \\
\text { Beverage: } \\
627.6 \mathrm{~kJ}\end{array}$ & $\begin{array}{l}240 \mathrm{ml} \\
175 \mathrm{mg} \\
\text { total phenols }\end{array}$ & TAG- & & $\mathrm{AC} \uparrow \mathrm{FRAP}$ & $\begin{array}{l}\text { TAG, NS } \\
\text { AC } \\
P<0.05\end{array}$ \\
\hline $\begin{array}{l}\text { Serafini } \\
\quad \text { et al. }{ }^{(96)}\end{array}$ & $\begin{array}{l}\text { Within subject } \\
\text { crossover } \\
2 t \times t \\
0-5 \mathrm{~h}\end{array}$ & 11 & $\begin{array}{l}\text { Healthy } \\
\text { M, F }\end{array}$ & $\mathrm{BB}$ & $\begin{array}{l}\text { Fresh fruit } \\
\quad+\text { whole milk }\end{array}$ & $\begin{array}{l}\text { BB + milk } \\
\text { BB + water } \\
\text { Beverage: } \\
543.92 \mathrm{~kJ}\end{array}$ & $\begin{array}{l}200 \mathrm{~g} \mathrm{FW} \\
250 \mathrm{mg} \\
\text { total phenols }\end{array}$ & TAG- & & $\begin{array}{l}\mathrm{AC} \uparrow \\
\wedge \text { TRAP } \\
\text { MFRAP }\end{array}$ & $\begin{array}{l}\text { TAG, NS } \\
\text { AC at } 5 \mathrm{~h} \\
\wedge P<0.05 \\
M P<0.001\end{array}$ \\
\hline $\begin{array}{l}\text { Ziegler } \\
\text { et al. }{ }^{(116)}\end{array}$ & $\begin{array}{l}\text { Parallel } \\
4 t \times t \\
0-24 \mathrm{~h}\end{array}$ & 60 & Healthy & RW & Beverage & $\begin{array}{l}\text { RW-1 } \\
\text { RW-2 } \\
\text { RW-3 } \\
\text { WW }\end{array}$ & $\begin{array}{l}300 \mathrm{ml} \\
\text { total phenols, } \\
\text { not specified }\end{array}$ & & LDLox- & $\begin{array}{l}\text { Plasma } \\
\text { Conjugated } \\
\text { dienes- } \\
\text { TBARS- }\end{array}$ & NS, NS \\
\hline
\end{tabular}

LDLox, LDL oxidation; AC, antioxidant capacity; M, male; F, female; RW, red wine; EtOH, ethyl alcohol; TRAP, total radical-trapping antioxidant parameter; post-M, postmenopausal; dyslip, dyslipidaemia; OW, overweight or obese; de-alco, de-alcoholised; CM, chylomicrons; Str, strawberry; Pbo, placebo; FD, freeze-dried; WBB, wild blueberry; ORAC, oxygen radical absorbance capacity; TAS, total antioxidant status; TEAC, trolox equivalent antioxidan capacity; GSE, grape seed extract; AP, apple polyphenol extract; CB, cranberry; vit C, vitamin C; BB, blueberry; J, juice; RW, red wine, WW, white wine; FRAP, ferric-reducing antioxidant power; TBAR, thiobarbituric acid reactive substances; $\downarrow$, decrease or reduction $(P<0.05) ; \uparrow$, increase $(P<0.05) ;-$, neutral, no effect $(P>0.05)$ compared with placebo or baseline (i.e. comparator trials).

* Describes general health, age or weight status. Healthy indicates normolipidaemic, between $>19$ years, not overweight or obese and no documented disease or condition.

tWhere meal is indicated, fruit or fruit-based beverage was consumed $5 \mathrm{~d}$ with the meal.

$\ddagger$ Meal is likely the same as that provided in reference Naissides et al. ${ }^{(78)}$.

$\S$ Time point that a second meal was introduced. The results represent the glucose and insulin responses to this point. 
was accompanied by a phenolic-rich treatment or placebo. In relatively healthy individuals consuming a moderate-/high-fat meal, strawberry ${ }^{(10)}$ and red wine ${ }^{(77)}$ blocked the postprandial rise in oxidised LDL or susceptibility of LDL to oxidation, respectively. GSE (300 mg capsule) with a highfat meal in healthy men enhanced LDL protection, but this was not statistically different from the meal with placebo capsule ${ }^{(97)}$. After a very low-fat meal (two plain bagels) ${ }^{(64)}$ or no meal challenge ${ }^{(116)}$, changes in LDL oxidation were neutral, suggesting that the benefit of polyphenol consumption with a meal is to attenuate or block meal-induced oxidative stress when the stress is sufficient to result in oxidised LDL. In type 2 diabetic subjects ${ }^{(54)}$, red wine attenuated mealinduced decrease in plasma antioxidant capacity (as measured by total radical-trapping antioxidant parameter) and partially protected LDL from the effect of the meal. Two investigations using a berry mix $(240 \mathrm{mg}$; $80 \mathrm{mg}$ each bilberries, lingonberries, black currant $)^{(101)}$ or cactus fruit $(500 \mathrm{~g})^{(117)}$ compared postprandial LDL oxidation susceptibility with baseline (fasting) susceptibility measurements (no placebo or other comparator) after consuming fruit alone. Consumption of berries resulted in improved antioxidant capacity with neutral effect on LDL oxidative susceptibility. Cactus fruit, rich in peroxyl-scavenging betalains resulted in decreased susceptibility of LDL to oxidation at 3 and $5 \mathrm{~h}$ postprandially. The effect appeared dependent on betalain accumulation in LDL and sparing effects of lipid-soluble antioxidants. As with much of the postprandial effects of fruits and their inherent phytochemicals, additional research is required to understand betalains and indicaxanthins in health protection.

The acute effect of increasing antioxidant capacity of plasma is fairly consistent; however, changes in a biological marker of disease risk are not always indicated. This may be due to a variety of reasons ranging from composition and dose requirements to elicit an effect to choice of marker being measured. In addition, polyphenolic compounds likely act beyond a classic 'antioxidant' role to impart benefit, and hence changes in antioxidant capacity may not necessarily predict a biological response. Likewise, the interrelationship between acute and long-term effects of polyphenolic compounds on disease risk, as studied in various acute and chronic feeding paradigms, requires continued attention to better understand the translation and predictability of our models to describe biological impact and mechanism of action in a preventative or potentially therapeutic role in certain populations.

\section{Other considerations}

Obesity is a major risk factor for metabolic syndrome which is characterised by dyslipidaemia, dysglycaemia, hypertension, insulin resistance, obesity (particularly central adiposity) and elevated inflammatory markers ${ }^{(118)}$. Recent interest has focused on insulin resistance as a linking factor. Weight loss, as little as $5 \%$ of body weight, can dramatically improve metabolic endpoints, including insulin resistance. The recent discovery of ghrelin synthesis and secretion in human stomach has generated a new context to the regulation of food intake and potential treatment options for obesity ${ }^{(119)}$. Ghrelin is the only known peripheral signal that increases food intake. During fasting, ghrelin concentrations are elevated, and after eating, ghrelin secretion is suppressed. Studies in human subjects indicate that ghrelin suppression is sensitive to meal composition and energy intake, rather than volume. Carbohydrate-rich meals appear superior to protein- or fat-rich meals in suppressing ghrelin concentrations postprandially ${ }^{(120)}$. An inverse relationship between insulin and ghrelin suggests that foods or meals that elicit sufficient insulin will also suppress ghrelin ${ }^{(76)}$. Fruit is a relatively carbohydrate-rich food; however, fruit is also low in energy, owing to its high water and indigestible carbohydrate content. Fruit delivers a variety of antioxidant compounds that could, via indirect redox-sensitive and anti-inflammatory mechanisms, influence postprandial insulin sensitivity. Improving postprandial insulin sensitivity would suggest a reduced insulin requirement with equitable glycaemic control, ghrelin suppression and managed appetite. Only one human trial was identified with exclusive fruit consumption in which ghrelin, insulin and glucose were measured in a postprandial testing paradigm ${ }^{(76)}$. Because satiation (the process that brings eating to end) was a primary component of the study design, fruit intake was not fixed. Therefore, results are based on the mean intake of fruit consumed by participants (693 (SD 73) g, 434 (SD 188.3) kJ (45 kcal)). Compared with a bread-based carbohydrate meal (257 (SD 21) g, $658(225.9) \mathrm{kJ}$ (54 kcal)), the fruit (bananas, kiwi and apple) produced only a modest glucose and insulin response. Ghrelin was suppressed after fruit intake when insulin was elevated (45-60 min); however, unlike the bread meal, insulin concentrations rapidly returned to baseline concentrations and over the course of the next $3 \mathrm{~h}$, ghrelin gradually rose eventually to above baseline concentrations during the last hour $(3-4 \mathrm{~h})$ before an $a d$ libitum lunch was served. This trial generates several interesting hypotheses worth exploring further. It stands to reason that dietary strategies that improve antioxidant and inflammatory status for cardio-metabolic health would also prove advantageous for food intake and body weight regulation; however, randomised controlled trials are required to verify this relationship.

\section{Conclusions}

The role of fruit phenolic compounds to protect health and lower disease risk is a topic of great interest. There is a paucity of research to support a reliable understanding of fruit phenolics, among other sources of phenolic compounds, in postprandial metabolic events. It is clear that the postprandial state is a dynamic state of potential instability. Disturbances in postprandial metabolism of glucose, lipids and lipoproteins are linked to chronic disease. In a single day, the systemic stress of hyperglycaemia, hyperlipaemia and redox imbalance may seem trivial. Over time, however, these daily insults can lead to an array of complicated health consequences, atherosclerosis being at the top contributing to the more than 829000 deaths a year in the United States ${ }^{(121)}$. Plant foods and particularly fruits rich in polyphenolic compounds may have a unique role in disease risk reduction through their actions in mitigating fed-state oxidative stressors that contribute to disease.

At the outset of this review, two main questions were posed: first, what is the role of plant foods, specifically fruits rich in complex and simple phenolic compounds in postprandial 
metabolic management; and second, does the evidence support consuming these fruits with meals as a practical strategy to preserve health and lower risk for disease? With regard to both questions, an important finding of this review was the lack of human trials examining the effect of fruits rich in phenolic compounds on postprandial clinical endpoints. Advances in technology allow us to detect, quantify and pre-clinically screen compounds of relevance in fruit and human specimen. The present work is ongoing and being published. Additionally, however, well-controlled trials in defined populations considering subject characteristics, present health status and confounding factors related to complex food systems influencing polyphenol actions will be critical for making reliable conclusions to base dietary recommendations on fruit or fruit-based products for maintenance of health and disease management plans. Notwithstanding the need for more research, the collected data suggest that consuming phenolicrich fruits increases the antioxidant capacity of the blood, and when they are consumed with high fat and readily available carbohydrate 'pro-oxidant and pro-inflammatory' meals, they may counterbalance their negative effects. Given the content and availability of fat and simple carbohydrates in the Western diet, regular consumption of phenolic-rich foods, particularly in conjunction with meals, appears to be a prudent strategy to maintain oxidative balance and health.

\section{Acknowledgements}

There are no conflicts of interest with the contents of the present paper. Funding for the writing of the present paper was provided by GlaxoSmithKline. B. B.-F. wrote the manuscript and prepared the tables and figure. The author thanks Dr Tissa Kappagoda and Dr Indika Edirisinghe for their thoughtful and constructive comments on the manuscript, tables and figure.

\section{References}

1. Hu FR, Rimm EB, Stampfer MJ, et al. (2000) Prospective study of major dietary patterns and risk of coronary heart disease in men. Am J Clin Nutr 72, 912-921.

2. Kant AK, Graubard BI \& Schatzkin A (2004) Dietary patterns predict mortality in a national cohort: the National Health Interview Surveys, 1987 and 1992. J Nutr 134, 1793-1799.

3. Mokdad AH, Marks JS, Stroup DF, et al. (2000) Actual causes of death in the United States. JAMA 291, 1238-1245.

4. Alipour A, Elte JWF, van Zaanen HCT, et al. (2007) Postprandial inflammation and endothelial dysfunction. Biochem Soc Trans 35, 464-469.

5. Nappo F, Esposito K, Coiffi M, et al. (2002) Postprandial endothelial activation in healthy subjects and in type 2 diabetic patients: role of fat and carbohydrate meals. J Am Coll Cardiol 39, $1145-1150$.

6. Sies H, Stahl W \& Sevanian A (2005) Nutritional, dietary and postprandial oxidative stress. Am Soc Nutr Sci 135, 969-972.

7. Rizzo M, Kotur-Stevuljevic J, Berneis K, et al. (2009) Atherogenic dyslipidemia and oxidative stress: a new look. Transl Res 153, 217-223.

8. Ursini F, Zamburlini A, Cazzolato G, et al. (1998) Postprandial plasma lipid hydroperoxides: a possible link between diet and atherosclerosis. Free Radic Biol Med 25, 250-252.

9. van Oostrom AJ, van Wijk JPH \& Cabezas MC (2004) Lipaemia, inflammation and atherosclerosis: novel opportunities in the understanding and treatment of atherosclerosis. Drugs 64, Suppl. 2, 19-41.

10. Burton-Freeman B, Linares A, Hyson D, et al. (2010) Strawberry modulates LDL oxidation and postprandial lipemia in response to high fat meal in overweight hyperlipidemic men and women. Am J Coll Nutr 29, 46-54.

11. Kris-Etherton PM, Lefevre M, Beecher GR, et al. (2004) Bioactive compounds in nutrition and health-research methodologies for establishing biological function: the antioxidant and anti-inflammatory effects of flavonoids on atherosclerosis. Anпи Rev Nutr 24, 511-538.

12. Most MM (2004) Estimated phytochemical content of the dietary approaches to stop hypertension (DASH) diet is higher than in the Control Study Diet. J Am Diet Assoc 104, $1725-1727$.

13. Knekt P, Kumpulainen J, Järvinen R, et al. (2002) Flavonoid intake and risk of chronic diseases. Am J Clin Nutr 76, 560-568.

14. Mennen LI, Sapinho D, de Bree A, et al. (2004) Consumption of foods rich in flavanoids to a decreased cardiovacular risk in apparently healthy French woman. Am Soc Nutr Sci 134, 923-926.

15. Rice-Evans CA, Miller NJ \& Paganga G (1996) Structureantioxidant activity relationships of flavonoids and phenolic acids. Free Radic Biol Med 20, 933-956.

16. Sampson L, Rimm E, Hollman PC, et al. (2002) Flavonol and flavone intakes in US health professionals. J Am Diet Assoc 102, 1414-1420.

17. Hertog M \& Kromhout D (1995) Flavonoid intake and longterm risk of coronary heart disease and cancer in the seven countries. Arch Intern Med 155, 381-386.

18. Hertog MG, Feskens EJ \& Kromhout D (1997) Antioxidant flavonols and coronary heart disease risk. Lancet 349, 699-703.

19. Pérez-Jiménez J, Neveu V, Vos F, et al. (2010) Systematic analysis of the content of 502 polyphenols in 452 foods and beverages: an application of the phenol-explorer database. J Agric Food Chem 58, 4959-4969.

20. Shanmuganayagam D, Beahm MR, Osman HE, et al. (2002) Grape seed and grape skin extracts elicit a greater antiplatelet effect when used in combination than when used individually in dogs and humans. J Nutr 132, 3592-3598.

21. Rein D, Paglieroni TG, Pearson DA, et al. (2000) Cocoa and wine polyphenols modulate platelet activation and function. J Nutr 130, Suppl. 8, 2120S-2126S

22. Zern TL \& Fernandez ML (2005) Cardioprotective effects of dietary polyphenols. J Nutr 135, 2291-2294.

23. Williams MJ, Sutherland WH, Whelan AP, et al. (2004) Acute effect of drinking red and white wines on circulating levels of inflammation-sensitive molecules in men with coronary artery disease. Metabolism 53, 318-323.

24. Agarwal C, Sharma Y \& Agarwal R (2000) Anticarcinogenic effect of a polyphenolic fraction isolated from grape seeds in human prostate carcinoma DU145 cells: modulation of mitogenic signaling and cell-cycle regulators and induction of G1 arrest and apoptosis. Mol Carcinog 28, 129-138.

25. Agarwal C, Sharma Y, Zhao J \& Agarwal R (2000) A polyphenolic fraction from grape seeds causes irreversible growth inhibition of breast carcinoma MDA-MB468 cells by inhibiting mitogen-activated protein kinases activation and inducing G1 arrest and differentiation. Clin Cancer Res 6, 2921-2930.

26. Crozier A, Jaganath IB \& Clifford MN (2009) Dietary phenolics: chemistry, bioavailability and effects on health. Nat Prod Rep 26, 1001-1043.

27. Prior R, Wu X \& Schaich K (2005) Standardized methods for the determination of antioxidant capacity and phenolics in foods and dietary supplements. J Agric Food Chem 53, $4290-4302$ 
28. Szajdek A \& Borowska E (2008) Bioactive compounds and health-promoting properties of berry fruits: a review. Plant Foods Hum Nutr (Dordrecht) 63, 147-156.

29. Vinson JA, Dabbagh YA, Serry MM, et al. (1995) Plant Flavonoids, especially tea flavonols, are powerful antioxidants using as in vitro oxidation model for heart disease. J Agric Food Chem 43, 2800-2802.

30. Vinson JA, So X, Zubik L, et al. (2001) Phenol antioxidant quality and quality in foods: fruit. J Agric Food Chem $\mathbf{4 9}$, 5315-5321.

31. Chun OK, Chung SJ \& Song WO (2007) Estimated dietary flavonoid intake and major food sources of U.S. adults. J Nutr 137, 1244-1252.

32. Cao J, Zhang Y, Chen W, et al. (2010) The relationship between fasting plasma concentrations of selected flavonoids and their ordinary dietary intake. Br J Nutr 103, 249-255.

33. Hertog GL, Kromhout D, Aravanis C, et al. (1995) Flavonoid intake and long-term risk of coronary heart disease and cancer in the seven countries study. Arch Intern Med 155, 381-386.

34. USDA database for the flavonoid content of selected foods. Release 2.1 Jan 2007. http://www.ars.usda.gov/nutrientdata (accessed September 2009).

35. Nijveldt RJ, van Nood E, van Hoorn DEC, et al. (2001) Flavonoids: a review of probable mechanisms of action and potential applications. Am J Clin Nutr 74, 418-425.

36. Galleano M, Verstraeten SV, Oteiza PI, et al. (2010) Antioxidant actions of flavonoids: thermodynamic and kinetic analysis. Arch Biochem Biophys 501, 23-30.

37. Afanas'ev IB, Dorozhko AI, Brodskii AV, et al. (1989) Chelating and free radical scavenging mechanisms of inhibitory action of rutin and quercetin in lipid peroxidation. Biochem Pharmacol 38, 1763-1769.

38. Ferrali M, Signorini C, Caciotti B, et al. (1997) Protection against oxidative damage of erythrocyte membrane by the flavonoid quercetin and its relation to iron chelating activity. FEBS Lett 416, 123-129.

39. Kostyuk VA, Potapovich AI, Strigunova EN, et al. (2004) Experimental evidence that flavonoid metal complexes may act as mimics of superoxide dismutase. Arch Biochem Biophys 428, 204-208.

40. Maenpaa PH, Raivio KO \& Kekomaki MP (1968) Liver adenine nucleotides: fructose-induced depletion and its effect on protein synthesis. Science 161, 1253-1254.

41. Heuckenkamp PU \& Zollner N (1971) Fructose-induced hyperuricaemia. Lancet 1, 808-809.

42. Cao G, Russell RM, Lischner N, et al. (1998) Serum antioxidant capacity is increased by consumption of strawberries, spinach, red wine or vitamin C in elderly woman. $J$ Nutr $\mathbf{9 8 ,}$ 2383-2309.

43. Lotito SB \& Frei B (2004) The increase in human plasma antioxidant capacity after apple consumption is due to the metabolic effect of fructose on urate, not apple-derived antioxidant flavonoids. Free Radic Biol Med 37, 251-258.

44. Ursini F \& Sevanian A (2002) Wine polyphenols and optimal nutrition. Ann N Y Acad Sci 957, 200-209.

45. Schreck R, Meier B, Mannel DN, et al. (1992) Dithiocarbamates as potent inhibitors of nuclear factor $\mathrm{kB}$ activation in intact cells. $J$ Exp Med 175, 1181-1194.

46. Blanco-Colio LM, Valderrama M, Alvarez-Sala LA, et al. (2000) Red wine intake prevents nuclear factor-kappaB activation in peripheral blood mononuclear cells of healthy volunteers during postprandial lipemia. Circulation 102, $1020-1026$.

47. Sandhya K, Tadapaneni R, Banaszewski K, et al. (2010) Strawberry extract attenuates oxidative stress-induced impaired insulin signaling in vitro in Human Skeletal Muscle Cells. FASEB $J$ 24, 541.13.
48. Lin CL \& Lin JK (2008) Epigallocatechin gallate (EGCG) attenuates high glucose-induced insulin signaling blockade in human hepG2 hepatoma cells. Mol Nutr Food Res 52, 930-939.

49. Ndiaye M, Chataigneau M, Lobysheva I, et al. (2004) Red wine polyphenol-induced, endothelium-dependent NOmediated relaxation is due to the redox-sensitive PI3-kinase/ Akt-dependent phosphorylation of endothelial NO-synthase in the isolated porcine coronary artery. FASEB $J$ 19, 455-457.

50. Edirisinghe I, Burton-Freeman B \& Tissa Kappagoda C (2008) Mechanism of the endothelium-dependent relaxation evoked by a grape seed extract. Clin Sci (Lond) 114, 331-337.

51. Edirisinghe I, Burton-Freeman B, Varelis P, et al. (2008) Strawberry extract caused endothelium-dependent relaxation through the activation of PI3 kinase/Akt. J Agric Food Chem 56, 9383-9390.

52. Manach C, Williamson G, Morand C, et al. (2005) Bioavailability and bioefficacy of polyphenols in humans. I. Review of 97 bioavailability studies. Am J Clin Nutr 81, Suppl. 1, 230S-242S.

53. Hollman PC, van Trijp JM, Buysman MN, et al. (1997) Relative bioavailability of the antioxidant flavonoid quercetin from various foods in man. FEBS Lett 418, 152-156.

54. Ceriello A, Bortolotti N, Motz E, et al. (2001) Red wine protects diabetic patients from meal-induced oxidative stress and thrombosis activation: a pleasant approach to the prevention of cardiovascular disease in diabetes. Eur J Clin Invest 31, $322-328$.

55. Chung BH, Hennig B, Cho BHS, et al. (1998) Effect of the fat consumption of a single meal on the composition and cytotoxis potencies of lipolytically-released free fatty acids in postprandial plasma. Atherosclerosis 141, 321-332.

56. Ceriello A, Taboga C, Tonutti L, et al. (2002) Evidence for an independent and cumulative effect of postprandial hypertriglyceridemia and hyperglycemia on endothelial dysfunction and oxidative stress generation: effects of short- and long-term simvastatin treatment. Circulation 106, 1211-1218.

57. Laakso M (1999) Hyperglycemia and cardiovascular disease in type 2 diabetes. Diabetes 44, 937-942.

58. Ceriello A (1998) The emerging role of post-prandial hyperglycaemic spikes in the pathogenesis of diabetic complications. Diabet Med 15, 188-193.

59. Stratton IM, Adler AI, Neil HA, et al. (2000) Association of glycaemia with macrovascular and microvascular complications of type 2 diabetes (UKPDS 35). BMJ 321, 405-412.

60. Fernandez-Panchon MS, Villano D, Troncoso AM, et al. (2008) Antioxidant activity of phenolic compounds: from In vitro results to In vitro evidence. Crit Rev Food Sci Nutr 48, 649-671.

61. Prior R, Gu L, Wu X, et al. (2007) Plasma antioxidant capacity changes following a meal as a measure of the ability of a food to alter in vivo antioxidant status. J Am Coll Nutr 26, 170-181.

62. Lotito SB \& Frei B (2004) Relevance of apple polyphenols as antioxidants in human plasma: contrasting in vitro and in vitro effects. Free Radic Biol Med 36, 201-211.

63. de Rijke YB, Demacker PN, Assen NA, et al. (1996) Red wine consumption does not affect oxidizability of low-density lipoproteins in volunteers. Am J Clin Nutr 63, 329-334.

64. Caccetta RAA, Croft KD, Beilin LJ, et al. (2000) Ingestion of red wine significantly increases plasma phenolic acid concentrations but does not acutely affect ex vivo lipoprotein oxidizability. Am J Clin Nutr 71, 67-74.

65. Ko S, Choi S, Ye S, et al. (2005) Comparison of the antioxidant activities of nine different fruits in human plasma. J Med Food 8, 41-46.

66. Carbonneau MA, Léger CL, Monnier L, et al. (1997) Supplementation with wine phenolic compounds increases the antioxidant capacity of plasma and vitamin $\mathrm{E}$ of 
low-density lipoprotein without changing the lipoprotein $\mathrm{Cu}(2+$ )-oxidizability: possible explanation by phenolic location. Evr J Clin Nutr 51, 682-690.

67. Williams RJ, Spencer JP, Rice-Evans C, et al. (2004) Flavonoids: antioxidants or signalling molecules? Free Radic Biol Med 36, 838-849.

68. Nivoit P, Wiernsperger N, Moulin P, et al. (2003) Effect of glycated LDL on microvascular tone in mice: a comparative study with LDL modified in vitro or isolated from diabetic patients. Diabetologia 46, 1550-1558.

69. Ceriello A, Quagliaro L, Catone B, et al. (2002) Role of hyperglycemia in nitrotyrosine postprandial generation. Diabetes Care 25, 1439-1443.

70. Diwadkar VA, Anderson JW, Bridges SR, et al. (1999) Postprandial low-density lipoproteins in type 2 diabetes are oxidized more extensively than fasting diabetes and control samples. Proc Soc Exp Biol Med 222, 178-184.

71. Steinberg D \& Lewis A (1997) Conner Memorial Lecture: oxidative modification of LDL and atherogenesis. Circulation 95, 1062-1091.

72. Berliner JA, Novab M, Fogelman AM, et al. (1995) Atherosclerosis: basic mechanisms - oxidation, inflammation and genetics. Circulation 91, 2488-2496.

73. Wilson T, Singh AP, Vorsa N, et al. (2008) Human glycemic response and phenolic content of unsweetened cranberry juice. J Med Food 11, 46-54.

74. Vinson JA, Bose P, Proch J, et al. (2008) Cranberries and cranberry products: powerful in vitro, ex vitro and in vitro sources of antioxidants. J Agric Food Chem 56, 5884-5891.

75. Kay CD \& Holub BJ (2002) The effect of wild blueberry (Vaccinium angustifolium) consumption postprandial serum antioxidant status in human subjects. Br J Nutr 88, 389-397.

76. Erdmann J, Topsch R, Lippl F, et al. (2004) Postprandial response of plasma ghrelin levels to various test meals in relation to food intake, plasma insulin, and glucose. $J$ Clin Endocrinol Metab 89, 3048-3054.

77. Natella F, Ghiselli A, Gudi A, et al. (2001) Red wine mitigates the postprandial increase of LDL susceptibility to oxidation. Free Radic Biol Med 30, 1036-1044.

78. Naissides M, Mamo J, James A, et al. (2004) The effect of acute red wine polyphenol consumption on postprandial lipaemia in postmenopausal women. Atherosclerosis 177, 401-408.

79. Pal S, Naissides M \& Mamo J (2004) Polyphenolics and fat absorption. Int $J$ Obes 28, 324-326.

80. Cermak R, Landgraf S \& Wolffram S (2004) Quercetin glucosides inhibit glucose uptake into brush-border-membrane vesicles of porcine jejunum. Br J Nutr 91, 849-855.

81. Strobel P, Allard C, Perez-Acle T, et al. (2005) Myricetin, quercetin and catechin-gallate inhibit glucose uptake in isolated rat adipocytes. Biochem J 386, Pt 3, 471-478.

82. Kannappan S \& Anuradha CV (2009) Insulin sensitizing actions of fenugreek seed polyphenols, quercetin \& metformin in a rat model. Indian J Med Res 129, 401-408.

83. Bashan N, Kovsan J, Kachko I, et al. (2009) Positive and negative regulation of insulin signaling by reactive oxygen and nitrogen species. Physiol Rev 89, 27-71.

84. Edirisinghe I, Krishnankutty S, Cappozzo J, et al. Postprandial oxidative/inflammatory-stress: restoring balance with strawberry polyphenols and exploring mechanisms of enhanced insulin signaling in vitro in human skeletal muscle cells (Submitted).

85. Patsch JR, Miesenbock G, Hopferwieser T, et al. (1992) Relations of triglyceride metabolism and coronary artery disease: studies in the postprandial state. Arterioscler Thromb 12, 1336-1345.

86. Bansal S, Buring JE, Rifai N, et al. (2007) Fasting compared with nonfasting triglycerides and risk of cardiovascular events in women. JAMA 298, 309-316.
87. Alipour A, Elte JWF, van Zaanen HCT, et al. (2008) Novel aspects of postprandial lipemia in relation to atherosclerosis. Atheroscler Suppl 9, 39-44.

88. Shoelson SE, Lee J \& Goldfine AB (2006) Inflammation and insulin resistance. J Clin Invest 116, 1793-1801.

89. Hyson DA, Paglieroni TG, Wun T, et al. (2002) Postprandial lipemia is associated with platelet and monocyte activation and increased monocyte cytokine expression in normolipemic men. Clin Appl Thromb Hemost 8, 147-155.

90. Motton DD, Keim NL, Tenorio FA, et al. (2007) Postprandial monocyte activation in response to meals with high and low glycemic loads in overweight women. Am J Clin Nutr 85, 60-65.

91. Esposito K, Nappo F, Marfella R, et al. (2002) Inflammatory cytokine concentrations are acutely increased by hyperglycemia in humans: role of oxidative stress. Circulation 106, 2067-2072.

92. Mohanty P, Hamouda W, Garg R, et al. (2000) Glucose challenge stimulates reactive oxygen species (ROS) generation by leucocytes. J Clin Endocrinol Metab 85, 2970-2973.

93. Fuhrman B \& Aviram M (2001) Flavanoids protect LDL from oxidation and attenuate atherosclerosis. Cur Opin Lipid 12, $41-48$.

94. Kris-Etherton PM, Lefevre M, Beecher GR, et al. (2004) Bioactive compounds in nutrition and health-research methodologies for establishing biological function: the antioxidant and anti-inflammatory effects of flavonoids on atherosclerosis. Annu Rev Nutr 24, 511-538.

95. Mazza G, Kay C, Cottrell T, et al. (2002) Absorption of anthocyanins from blueberries and serum antioxidant status in human subjects. J Agric Food Chem 50, 7731-7737.

96. Serafini M, Testa MF, Villaño D, et al. (2009) Antioxidant activity of blueberry fruit is impaired by association with milk. Free Radic Biol Med 46, 769-774.

97. Natella F, Belelli F, Gentili V, et al. (2002) Grape seed proanthocyanidins prevent plasma postprandial oxidative stress in humans. J Agric Food Chem 50, 7720-7725.

98. Sugiyama H, Akazome Y, Shoji T, et al. (2007) Oligomeric procyanidins in apple polyphenol are main active components for inhibition of pancreatic lipase and triglyceride absorption. J Agric Food Chem 55, 4604-4609.

99. Décordé K, Teissedre Pl, Sutra T, et al. (2009) Chardonnay grape seed procyanidin extract supplementation prevents high-fat dietinduced obesity in hamsters by improving adipokine imbalance and oxidative stress markers. Mol Nutr Food Res 53, 659-666.

100. Imazu M, Ono K, Tadehara F, et al. (2008) Plasma levels of oxidized low density lipoprotein are associated with stable angina pectoris and modalities of acute coronary syndrome. Int Heart J 49, 515-524.

101. Berliner JA, Navab M, Fogelman AM, et al. (1995) Atherosclerosis: basic mechanisms. Oxidation, inflammation, and genetics. Circulation 91, 2488-2496.

102. Lu C, Gao Y, Zhou H, et al. (2008) The relationships between PON1 activity as well as oxLDL levels and coronary artery lesions in CHD patients with diabetes mellitus or impaired fasting glucose. Coron Artery Dis 19, 565-573.

103. Meisinger C, Baumert J, Khuseyinova N, et al. (2005) Plasma oxidation low-density lipoprotein, a strong predictor for acute coronary heart disease events in apparently healthy middle-aged men from the general population. J Am Heart Assoc 112, 651-657.

104. Miyagi Y, Miwa K \& Inoue H (1997) Inhibition of human low-density lipoprotein oxidation by flavonoids in red wine and grape juice. Am J Cardiol 80, 1627-1631.

105. Neri S, Signorelli SS, Torrisi B, et al. (2005) Effects of antioxidant supplementation on postprandial oxidative stress and endothelial dysfunction: a single-blind, 15-day clinical trial in patients with untreated type 2 diabetes, subjects with impaired glucose tolerance, and healthy controls. Clin Ther 27, 1764-1773. 
106. Parker TL, Wang XH, Pazmiño J, et al. (2007) Antioxidant capacity and phenolic content of grapes, sun-dried raisins, and golden raisins and their effect on ex vivo serum antioxidant capacity. J Agric Food Chem 55, 8472-8477.

107. Marniemi J, Hakala P, Mäki J, et al. (2000) Partial resistance of low density lipoprotein to oxidation in vivo after increased intake of berries. Nutr Metab Cardiovasc Dis 10, 331-337.

108. Lapointe A, Couillard C \& Lemieux S (2006) Effects of dietary factors on oxidation of low-density lipoprotein particles. $J$ Nutr Biochem 17, 645-658.

109. Aviram M, Dornfeld L, Resenblat M, et al. (2000) Pomegranate juice consumption reduces oxidative stress, atherogenic modifications to LDL, and platelet aggregation: studies in humans and in atherosclerotic apolipoprotein E-deficient mice. Am J Clin Nutr 71, 1062-1076.

110. Lechleitner M, Hoppichler F, Föger B, et al. (1994) Lowdensity lipoproteins of the postprandial state induce cellular cholesteryl ester accumulation in macrophages. Arterioscler Thromb 14, 1799-1807.

111. Wolff SP \& Nourooz-Zadeh J (1996) Hypothesis: UK consumption of dietary lipid hydroperoxides - a possible contributory factor to atherosclerosis. Atherosclerosis 119, 261-263.

112. Aviram M, Kaplan M, Rosenblat M, et al. (2005) Dietary antioxidants and paraoxonases in LDL oxidation and atherosclerosis development. Handb Exp Pharmacol 170, 263-300.

113. Lamuela-Raventos RM, Covas MI, Frito M, et al. (1999) Detection of dietary antioxidant phenolic compounds in human LDL. Clin Chem 45, 1870-1872.
114. Witzum JL (1994) The oxidation hypothesis of atherosclerosis. Lancet 344, 793-795.

115. Tikkanen KJ, Wahala K, Ojala S, et al. (1998) Effect of soybean phytoestrogen intake on low density lipoprotein oxidation resistance. Proc Natl Acad Sci USA 95, 3106-3110.

116. Ziegler S, Kostner K, Thallinger C, et al. (2005) Wine ingestion has no effect on lipid peroxidation products. Pharmacology 75, 152-156.

117. Tesoriere L, Allegra M, Butera D, et al. (2004) Absorption, excretion, and distribution of dietary antioxidant betalains in LDLs: potential health effects of betalains in humans. Am J Clin Nutr 80, 941-945.

118. Alberti KG, Eckel RH, Grundy SM, et al. (2009) Harmonizing the metabolic syndrome: a joint interim statement of the International Diabetes Federation Task Force on Epidemiology and Prevention; National Heart, Lung, and Blood Institute; American Heart Association; World Heart Federation; International Atherosclerosis Society; and international association for the Study of Obesity. Circulation 120, 1640-1645.

119. Kojima M, Hosoda H, Date Y, et al. (1999) Ghrelin is a growth-hormone-releasing acylated peptide from stomach. Nature 402, 656-660.

120. Erdmann J, Lipple F \& Schusdziarra V (2003) Differential effect of protein and fat on ghrelin levels in man. Regul Pept 116, 101-107.

121. Lloyd-Jones D, Adams R, Carnethon M, et al. (2009) Heart disease and stroke statistics - 2009 update: a report from the American Heart Association Statistics Committee and Stroke Statistics Subcommittee. Circulation 119, 480-486. 